\title{
NOTES ON DISTRIBUTION OF MYOTIS LEIBII IN EASTERN MONTANA
}

by Jon E. Swenson, Shepherd, Montana

The range of the Small-footed Bat (Myotis leibii) in eastern Montana is poorly known and the occurrence of this species in Montana needs further documentation (Hoffmann and Pattie, 1968). M. leibii has previously been collected at only three localities in Montana east of the continental divide in Miles City, Custer County (Hall and Kelson, 1959), Big Timber, Sweet Grass County, and two miles west of Fort Howes Ranger Station, Powder River County (Hoffmann, et al., 1969). Two other locations, Miles City, and a site eight miles north and 7.5 miles west of Amidon, Slope County, North Dakota (Jones and Stanley, 1962) represent the marginal records of the known range of $M$. leibii in this area.

A single male $M$. leibii ciliolabrum was captured alive in a building in Glendive, Dawson County, Montana (elevation 2,070 feet), by Art Barz on August 19, 1968. I received the bat on August 20, 1968 and preserved it as a study skin and skull, which have been deposited as no. 4975 in the Montana State University Zoological Museum at Bozeman. The measurements are: total length, $82 \mathrm{~mm}$; length of tail, 35 $\mathrm{mm}$; length of hind foot, $7 \mathrm{~mm}$; length of ear from notch, $15 \mathrm{~mm}$; and testes, $3 \times 2$. The bat weighed 3.5 grams when I obtained it. This locality represents a range extension of about 75 miles northeast of Miles City and about 75 miles northwest of Amidon.

On March 18, 1970, $14 M$. leibii ssp. were found hibernating in an abandoned coal mine 20 miles south of Roundup, Musselshell County, Montana (elevation about 3,300 feet). Twenty-two Western Big-eared Bats (Plecotus townsendii pallescens) were hibernating in the same mine, but the entire mine was not searched. Four $M$. leibii (three males and one female) were collected. Two of the specimens were deposited in MSUZM, one in the University of Montana Zoological Museum at Missoula, and one in the private collection of D. P. Hendricks. This locality does not represent a range extension, but it helps fill the hiatus between Miles City, about 130 miles east by northeast, Big Timber, about

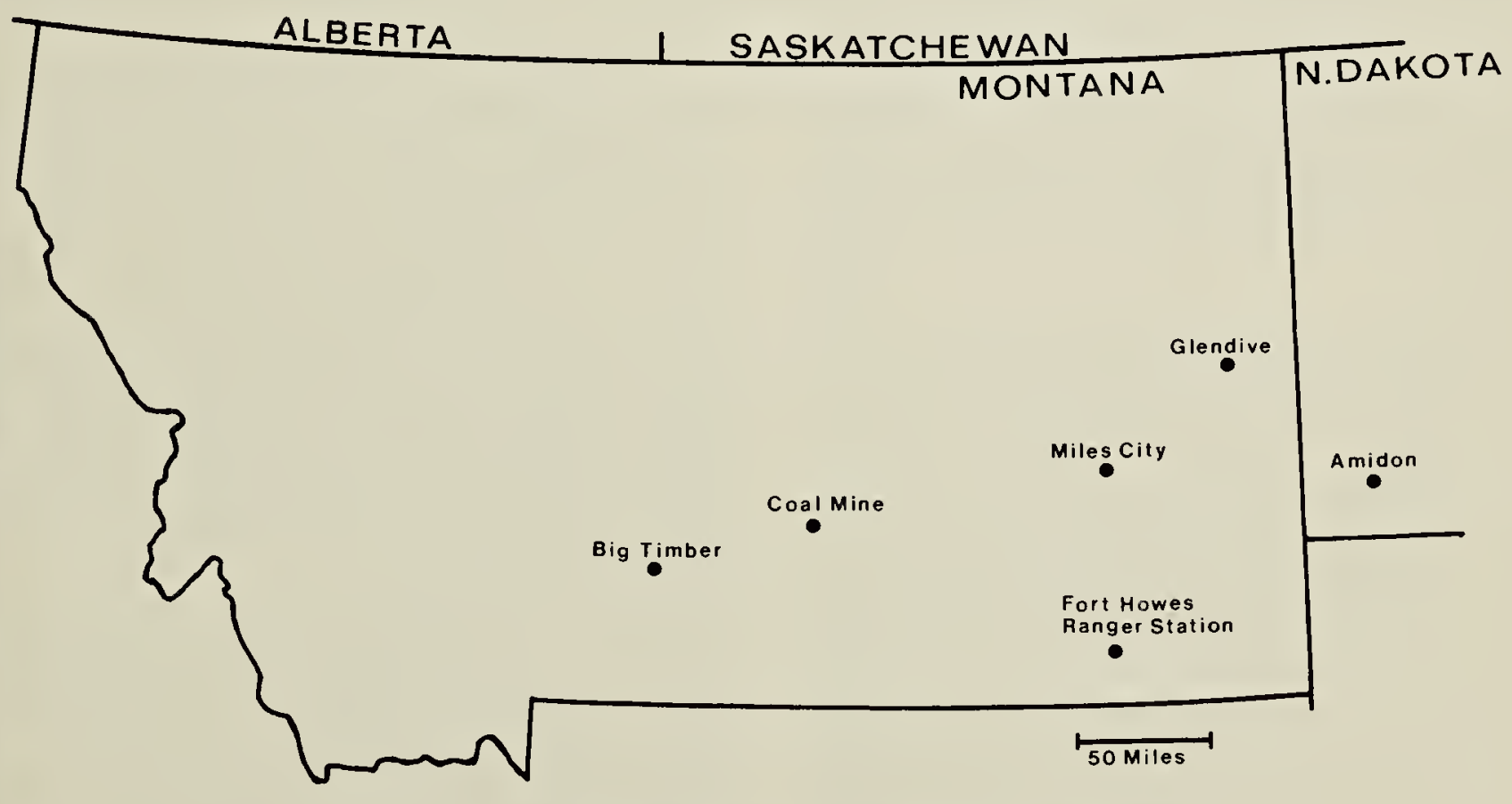

COLLECTION LOCALITIES OF MYOTIS LEIBII 
180 miles southwest, and Fort Howes Ranger Station, about 125 miles southeast of the coal mine.

These two observations help support the belief of Hoffmann, et al., (1969) that $M$. leibii probably occurs throughout the state.

I would like to thank Mr. Barz and Mr. Don MacDonald for bringing the $M$. leibii specimen to me, D. P. Hendricks for helping me collect and preserve the bats collected in the mine, Dr. Robert E. Moore for reviewing the manuscript, and Dr. J. Knox Jones for referring the specimens to subspecies.

\section{LITERATURE CITED}

Hall, E. R., and K. R. Kelson. 1959. The mammals of North America. Ronald Press, New York. 1: 1-546.

Hoffmann, R. S., and D. L. Pattie. 1968. A guide to Montana mammals; identification, habitat, distribution and abundance. Univ. Montana Print Serv., Missoula. 133pp.

Hoffmann, R. S., D. L. Pattie and J. F. Bell. 1969. The distribution of some mammals in Montana. II. Bats. J. Mammal., 50 :737-741.

Jones, J. K., Jr., and W. C. Stanley. 1962. Myotis subulatus in North Dakota. J. Mammal., $43: 263$.

\section{Junior Naturalists}

\section{Edited by Joyce Deutscher, 7200 6th Ave., Regina}

\section{DOG WITH OVER 600 PORCUPINE QUILLS}

by Rosemary Nemeth, age 15, Yellow Creek

I never knew how deadly porcupines could be until an incident happened.

I usually go for a walk in the fall through the bush. I just can't resist the beauties the bush has to offer. Puppy, our dog, always comes along with me wherever I go. Puppy is about six inches high and about a foot and a half long.

First we went to a slough. We walked around the slough trying to see if there were any new muskrat houses. We saw one muskrat house which the muskrats had been working on. Then I decided to go to another slough about a quarter of a mile from the first slough.

To get to the second slough we had to walk across a stubble field and on the stubble field was a little bluff of trees. Puppy ran into this bluff. I didn't really pay attention to where he went because he usually wanders off when he wants to, but he always comes back to me.

Then all of a sudden I heard a terrible cry. The first thing that struck me was to run. I ran for a short distance, stopped and called for Puppy but he didn't come. So I went home and told my mother what happened. She told me, "Don't worry, he'll come home". But I didn't believe her, so I started to go back to where I had left Puppy.

Dad and my brothers were hauling bales and they drove in front of me. I saw Dad stop and then I saw Puppy. Puppy's whole side was white with porcupine quills. Dad and my brothers. went to him. By the time I got there, Dad and my brothers had started to pull some quills out, but because it was impossible to get many of them out, we took Puppy to a veterinarian.

The vet put Puppy to sleep and he and my brother started to pull quills out with a certain kind of tool. It took about half an hour to get all the quills out they could find. The vet said you could never get all the quills out. The vet estimated Puppy had about 400 quills and my Dad and my brothers pulled out about 200 quills before we took Puppy to the vet. Then the vet gave Puppy a penicillin shot to prevent infection.

For a few days Puppy was pretty stiff. But he managed to pull through and now he is just as good as ever. I hope this never happens again because I know how some poor wild animal has to suffer with porcupine quills before it dies. 